\title{
Teachers' Regular Supervision and Student Academic Performance in Public Secondary Schools in Ekiti State, Nigeria
}

\author{
BOLARINWA Dapo Alonge (Corresponding Author) \\ Department of Educational Management \\ Ekiti State University, Ado-Ekiti, Nigeria \\ Tel: 234-903-383-9073Ｅ-mail: dapo.bolarinwa@eksu.edu.ng \\ OGUNMILADE Johnson Olusesan \\ Department of Vocational and Technical Education \\ Ekiti State University, Ado-Ekiti, Nigeria \\ Tel: 234-806-015-3506_E-mail: olusesan.ogunmilade@eksu.edu.ng
}

BAMIKOLE Oloruntoba

Department of Educational Management

Ekiti State University, Ado-Ekiti, Nigeria

Tel: 234-803-524-7431_E-mail: tobagreat@gmail.com

Received: September 2, 2021

Accepted: October 7, $2021 \quad$ Published: October 10, 2021

doi: 10.5296/ire.v9i2.19082

URL: https://doi.org/10.5296/ire.v9i2.19082

\begin{abstract}
The poor academic performance of students could be as a result of irregular supervision of teachers. The study investigated the relationship between teachers' regular supervision and student academic performance in public secondary schools in Ekiti State, Nigeria. Descriptive survey and correlational research were used for the study. The population for this study was 203 schools and 7,538 teachers in public secondary schools in Ekiti State, Nigeria.
\end{abstract}


Validated instrument titled “Teachers' Regular Supervision Questionnaire (TRSQ) was employed to collect data from the sample while a profoma was used to obtained data for academic performance of students. The study revealed that there was a positive significant relationship between regular supervision of teachers and student academic performance in public secondary schools in Ekiti State, Nigeria. The study recommended that principals and other internal supervisors should ensure regular supervision of teachers.

Keywords: Regular Supervision, Supervision, Performance, Academic Performance, Public Secondary Schools

\section{Introduction}

According to Adeyemi (2008), students' academic performance can simply be viewed as an outcome of all academic tasks or rigors of students which could be poorly or successfully expressed. Looking at the huge amount of money that government invested in education, the researchers observed decline in the student academic performance in both internal and other examinations in public secondary schools in Ekiti State. This perception was set up by Ayeni (2012) who believed that the normal level of the students who got credit level pass in the West African Senior School Certificate (WASSCE) dealt with by the West African Examinations Council (WAEC) in subjects over five including Mathematics and English Language somewhere in the range of 2010 and 2014 was about $23 \%$ in Nigeria. For instance, the West African Examinations Council aftereffect of 2014 showed that solitary 62,295 of the 310,077 up-and-comers (20.04\%) passed with credit in five subjects including Mathematics and English Language (www.vanguardngr.com).

Sam (2011) lamentably saw that the secondary school student academic performance in Nigeria is poor as found in the aftereffects of the national examinations directed by the West African Examinations Council, the National Examinations Council (NECO) and the Joint Admissions Matriculation Board (JAMB). As indicated by Sam (2011), 46.75\% of the applicant who sat for the assessment got over six credits passes and $58.05 \%$ of the up-and-comers who sat for the assessment got over five credits passes.

The above situation does not exclude Ekiti State going by the performance of students who sat for the West African Senior School Certificate Examinations from 2012 to 2019 and this may not be unconnected with the seemingly inconsistencies in the level of supervision within the framework of Nigerian secondary education.

Teachers' regular supervision appears to be the utmost importance for the implementation and actualization of educational objectives but it has been observed by the researchers that the routines and quality of supervision by the school administrators and government agencies has diminished which may prompt inadequate educational plan conveyance and poor academic performance of students. The researchers observed that vast majority of the teachers combined with all the school programmes were not consistently supervised; a significant number of the teachers have seen to have isolated faithfulness, non-challant mentality and are not endeavor their showing teaching duties with earnestness that the profession deserves to have the option to pass the correct information across to the students which in turn, may lead to helpless academic performance of the students. In this equivalent vein, it is debilitating that many school directors who should carry out supervision of instruction are more often than not, 
occupied with the managerial assignments in their workplace. It shows up, they once in a while visit the classroom to see whether teachers are going to classes on regular basis. The current circumstance of supervision in schools as announced by Luthans (2007) appeared there has not been exhaustive supervision of schools in ongoing past many years.

As indicated by Arogundade (2009) referred to in Bolarinwa (2014), supervision is the sensory system of any association. Stephen (2014) characterized supervision as a particular master activity in which education and training pointed toward creating science-educated practice are worked with through a teamed up relational cycle. It includes perception, assistance and supervisee self-appraisal, assessment, feedback and the getting of data and capacities by direction, showing, and basic reasoning. Similarly, by developing the affirmation of the characteristics and capacities of the supervisee, supervision enables self-adequacy. Igwe (2005) referred to in Ogunsola (2018) believed that concerning the current national policy on education, the supervision of instruction is the rout toward regulating crafted by teachers determined to assist them with handling their informative issues so students can benefit maximally from the classroom exercises.

As indicated by Okendu (2012), in the contemporary Nigeria, supervision is seen as the route toward upgrading the expert improvement of the teachers, the educational plan and improving the strategies of instructing in the classroom through fair associations between the teacher and the supervisor. In the expressions of Maulana (2012), education supervision has three measurements: organisation to accomplish learning goals, execution of educational plan; and guidance as indicated by the arrangement of learning project and its application.

According to Sregiovanni and Starrat (2006) cited in Ogunsola (2018) who stressed supervision as promising circumstances gave to teacher to fostering their abilities towards contributing towards students' scholastic achievement. Supervision is a nonstop movement of observing instructional process, arrangement of direction administration while building up a two route correspondence in a community relationship to improve scholastic execution of students. Supervision is likewise a developmental cycle which gives a chance to foster their abilities towards adding to students' scholastic achievement. It was additionally seen that supervisions correspond with brilliant educational cycle subsequently expanding the student scholarly result. (Afianmagbon, 2004 cited in Ogunsola, 2018). Also, Ayeni (2012) explored the connection among supervision and student academic performance, showed that supervision is very imperative to the accomplishment of school objectives.

In the views of Owadie (2011), there are two broad ways by which academic performance can be defined. The first way which could be looked at as more objective because, it looks into the numerical scores of student's knowledge that measure the extent of a student's adaptation to school work and to the system of education. The second way has its determination of academic success of students on the student's attitudes towards his or her academic achievement and himself or herself as well as by the attitudes other people that are so significant towards his or her success and himself or herself.

According to Owoyemi (2000) cited in Ajayi (2019), academic performance as a term has been defined as the scholastic attainment of a student at a given time. This scholastic attainment could be described as the scores obtained in a course or some courses offered. It refers to how an individual is able to demonstrate his or her intellectual abilities. This 
scholastic standing could be explained as the grades obtained in a course or group of courses taken. In the same vein, Arafat (2015) made comments on the scholastic standing of students and argued that performance is a measure of output and that the main outputs in education are expressed in terms of learning. That is, changes in knowledge, skills and attitudes of individuals as a result of their experiences within the school's system. Therefore, in determining the academic performance, Owadie (2011) emphasized the use of grades in examinations and reported that grades could serve as prediction measures and as criterion measures.

According to Kathryn (2010) student academic performance identifies with scholarly subjects that a student concentrates in school and the abilities the student is relied upon to procure in each subject. Steinberger (2005) cited in Ajayi (2019) said, academic performance covers ability of a student and his or her performance; it is multi-dimensional; it is inwardly related to human growth and cognitive; emotional and social-actual turn of event; it mirrors the whole kid. He further said that academic performance is not identified with an occasion, yet happens across time, levels, through the existence season of a student in public school and into tertiary institutions years and working life.

According to Bell (2011) considered academic performance to be as an element of numerous elements, some of which are inside the student and the classroom while others are outside of the study hall. Be that it may, Omotoso (2009) referred to in Ilesanmi (2017) credited lackluster showing of students to causes recognizable to government, for example, poor staffing in schools, insufficient motivations to teachers, frail inspectorate and flawed admission policy as well as high pace of teachers' turnover; causes detectable to parents include, incessant withdrawal of kids from schools and broken homes; causes discernible to students include, delinquency, delay to class, sluggishness with respect to numerous students, lazy disposition with respect to numerous students and negative group influence; causes traceable to teachers include, terrible preparation for class and teaching, negative supervision of students' work, unwillingness to make sacrifice and failure of some instructors to expand themselves academically and professionally; and causes traceable to the society consist of, wrong societal values on the part of the students, indiscipline inside the society and inadequate involvement of the society in the running of education. Akinfolaju (2012) reported that academic performance of student is a feature of proper teachers and availability of adequate facilities and instructional materials in the schools that will assure adequate teaching and learning.

In views of Ayo (2000) cited in Daramola (2017) academic performance of student is the end result of student's evaluation through a way achieving, methodical, mixture, demonstrative, developmental and assumptive assessment of what they have gone through in a school setting. Kayode and Ayodele (2015) opined that scholar scholastic execution alludes to how college students manipulate their examinations and how they live alive with or gain accomplishment in numerous errands given to them by means of their teachers.

According to Adebule (2013) academic performance of student may be measured through examinations, continuous examinations and checks. He burdened that it is through examination that the students' understanding and talents may be measured. Okorie (2014) argued that teachers appraise students within the shape of assignments, checks and 
examinations to relate how nicely they have accomplished. He went in addition that for general evaluation, college students exhibit their insight by using stepping through composed and oral examinations, acting introductions, entries of schoolwork and taking part in class exercises and verbal exchange. However, Blankstein (1996) cited in Ilesanmi (2017) stated that students' check scores and grades are not desirable indices of the quality instruction of teachers. Popoola (2017) was of the opinion that there have to be huge concurrence on how it is miles first-class attempted or which viewpoints is most primary procedural facts, for example, potential or explanatory statistics like truth.

According to Brumbach (1998) cited in Adeyanju (2018) college students' academic performance is behavior and consequences. In line with the above announcement, Oyedele (2004) cited in Daramola (2017) looked at academic performance of student as alluring changes or results in students' conduct after a time of teaching and learning in schools for the assurance of viability of teaching and learning as related to educational objectives which provide information to students, teachers, school administrators and parents on the level at which educational objectives have been achieved. However, Maimela and Monyatsi (2016) in their study titled, systems for improving the scholastic execution of students in Botswana elementary schools only found out that parental inclusion, framework arrangement and human resource were the elements affecting scholastic performance of students.

\subsection{Path-Goal Theory}

Path-goal theory depends on theories of motivation (expectancy motivation) created by Vroom yet applied in leadership studies by House in 1971. The expectancy theory from which this theory infers expresses that an employee's motivation depends on his expectancy that a certain effort level can be achieved by him and that the achievement of this level of performance is instrumental to the attainment of his personally desired outcomes.

According to Glickman, Gordon and Rose-Gordon (2007), one of the most significant elements of the school head is that of being an educational pioneer. The school head manages teaching and learning in the school to guarantee that quality instruction takes place. Fadipe (2000) cited in Dojumo (2019) opined that quality in instructive framework incorporate, nature of information sources, teachers, instruction and assessment techniques and others which should be appropriately administered for sustenance. The above statement is in accordance with the National Policy in Education (NPE) that said, supervision is an aspect to guarantee quality and ceaseless observing of instruction and other instructive administrations (Federal Republic of Nigeria, 2014). In addition, Nwagwu (2004) cited in Akinfolarin, Babalola and Aladetan (2017) posited that the supervisor has the responsibility of monitoring and evaluating all staff activities and programmes of their organization. The major reason for this is to ensure dutiful compliance of all teachers with the established laws and declared goals through quality assurance, maintenance of standards and quality control.

According to Bernad and Goodyear (2004) cited in Ankoma-Sey and Maina (2016) supervision is an intervention that is provided by a senior member of a profession to a junior member or members of that same profession. This relationship is evaluative, extend over time, and has the simultaneous purposes of enhancing the professional function of the junior professional(s), monitoring the quality of professional services offered to the clients she, he or they see, and serving as a gatekeeper of those who are to enter the particular profession. 


\section{Macrothink}

The behavior of the leader is satisfactory to the subordinates just on the off chance that they keep on considering the leader as a wellspring of fulfillment. The leader is seen as the motivator whose duty is to ensure adequate rewards to subordinates who work for organizational goals. In a nutshell, this theory underscores the part of the leader in persuading subordinates to act wanted way that will work with the achievement of hierarchical objectives. House (1971) kept up that the best chief assists subordinates with accomplishing both authoritative and individual objectives through inspiration.

In adjusting path-goal theory to the educational settings, "subordinate" can mean "teacher" and hold that teacher sees the leader as a source of satisfaction. The school head is seen as the motivator whose duty is to ensure adequate rewards to the teachers who work for educational or school goals. It must be submitted at this juncture that there are levels of supervision and its motivation is to assist teachers with monitoring imperfections in their teaching and the ramifications for the academic performance of their students.

\section{Method}

The descriptive survey and correlational research methods were utilized for this investigation. The population of the study consisted of 203 schools and 7,538 teachers in public secondary schools in Ekiti state, Nigeria as at the time of this study (source: Ekiti State Teaching Service Commission). The sample for the study consisted of 500 teachers selected through proportionate simple random technique.

Multistage sampling method was utilized for the investigation. The main stage included the utilization of simple random sampling strategy to choose two Neighborhood Government Regions from every one of the three Senatorial Areas. The subsequent stage included the determination of 50 schools from the chose Neighborhood Government Regions utilizing the stratified simple random sampling technique. The third and the last stage involved the selection of 10 teachers from each of the 50 schools using proportionate simple random sampling technique.

An instrument tagged, Teachers' Regular Supervision Questionnaire (TRSQ) was designed and adopted to collect data for this study. An inventory was also used. That is, the students' results. The instrument was shown to specialists in Tests and Measurement and Educational Management who read and checked the contents for clarity of the items for face and content validities. The study was subjected to test-re-test method and the reliability co-efficient (r) calculated was 0.72 which was high enough to ensure the reliability of the instrument. The hypothesis formulated was tested at 0.05 level of significance using Karl Pearson product moment correlation statistics.

\section{Result}

The null hypothesis formulated for this study was tested as shown in Table 1. 
Table 1. Test of relationship between teachers' regular supervision and academic performance of students

\begin{tabular}{llllll}
\hline Variables & $\mathrm{N}$ & & $\mathrm{SD}$ & r-cal & r-tab \\
& & $\bar{x}$ & & & \\
& & & & & \\
\hline Teachers' regular supervision & 500 & 13.26 & 1.11 & $0.523^{*}$ & 0.088 \\
Academic performance of students & 500 & 41.08 & 6.52 & & \\
\hline
\end{tabular}

Note: $* \mathrm{p}<0.05$ (significant result).

The table above shows the relationship between teachers' regular supervision and academic performance of students. The result obtained from the analysis shows that the value of $r$-cal $(0.523)$ is greater than r-table value (0.088). Therefore, the null hypothesis earlier formulated is rejected. This then implies that, there is significant positive relationship between teachers' regular supervision and academic performance of students.

\section{Discussion}

The study revealed that there was significant positive relationship between teachers' regular supervision and academic performance of students. The probable reason for this finding could be because supervisory needs of teachers were being met from time to time to improve teaching and learning processes. This means that teacher' regular supervision will improve the academic performance of students. The finding is in accordance with that of Federal Republic of Nigeria (2014) that asserted that supervision is an aspect to ensure quality and continuous monitoring of instruction and other educational services; Borman (2015) and Onuna (2015) who described supervision as the process which involved guiding and directing subordinates towards achieving success; Igwe (2005) cited in Ogunsola (2018) who opined that with regards to the current educational policy, the supervision of instruction is the process of overseeing the work of teachers with the aim of assisting them to solve their instructional problems so that students can benefit maximally from the classroom activities; Sregiovanni and Starrat (2006) cited in Ogunsola (2018) who emphasized supervision as opportunities provided to teachers to developing their capacities towards contributing towards students' academic success; Ayeni (2012) who opined that supervision is necessary in schools to achieve school objectives (e.g academic performance of students); and Leithwood, Saeshore-Louis, Anderson and Wahlstron (2004) as reported by Bolarinwa (2014) who opined that viable instruction leadership influences the nature of teaching and students' learning.

\section{Conclusion}

The investigation was able to review various literatures that are of relevance to teachers' regular supervision and academic performance of students. Based on the finding of this investigation, it was concluded that teachers' regular supervision is a necessary ingredient for enhancing academic performance of students

\section{Acknowledgements}

We acknowledge with thanks and immense gratitude, all the authors cited in this study, and 
the ideas borrowed from published and unpublished materials. We sincerely appreciate ourselves for selfless efforts during the course of carry out the research work. Dr Bolarinwa Dapo Alonge is sincerely appreciated for the typing of the manuscript and submission. Thanks.

\section{References}

Adebule, H. T. (2013). Enrolment and human resources as correlates of academic performance of secondary school students in Ekiti State, Nigeria. Unpublished M.Ed Thesis, Department of Educational Management, Faculty of Education, Ekiti State University, Ado-Ekiti, Nigeria.

Adeyanju, J. O. (2018). Teacher turnover and students' academic performance in secondary schools in Southwest, Nigeria. Unpublished PhD Thesis, Department of Educational Management, Faculty of Education, Ekiti State University, Ado-Ekiti, Nigeria.

Adeyemi, T. O. (2008). Predicting students' performance in Senior Secondary Certificate Examination from Junior Secondary Certificate Examination in Ondo State, Nigeria. Humanity and Social Science Journal, 3(1), 26-36. https://doi.org/10.4314/ajesms.v4i1.38622 Ajayi, A. O. (2019). Teacher factors as correlates of student academic performance in Ekiti State secondary schools. Unpublished M.Ed Thesis, Department of Educational Management, Faculty of Education, Ekiti State University, Ado-Ekiti, Nigeria.

Akinfolaju, J. (2012). Socio-Economic determinants of secondary school students' academic performance in Southwest, Nigeria. Unpublished $\mathrm{PhD}$ Thesis, Department of Educational Management, Faculty of Education, University of Ibadan, Ibadan, Nigeria.

Akinfolarin, C. A., Babalola, C. A., \& Aladetan, F. I. (2017). Academic supervision as correlate of students' academic performance in secondary schools in Ekiti State, Nigeria. International Journal of Educational Policy Research and Review, 4(1), 8-13.

Akinleye, G. A. (2011). Supervisors' and students' attitudes towards thesis writing. Being the text of a paper delivered at the second Postgraduate Seminar of the Faculty of Education, Ekiti State University held on the $17^{\text {th }}$ November.

Ankoma-Sey, V. R., \& Maina, B. (2016). The role of effective supervision on academic performance of Senior High Schools in Ghana. Journal of Arts and Humanities, 5(4), 73-83.

Arafat, O. S. (2015). A comparative study of student academic performance in urban and rural secondary schools: Its implication for educational planning. Unpublished M.Ed Thesis, Department of Educational Administration, Faculty of Education, University of Lagos, Nigeria.

Ayeni, A. J. (2012). Assessment of principals' supervisory roles for quality assurance in secondary schools in Ondo State, Nigeria. World Journal of Education, 2(1), 62-69. https://doi.org/10.5430/wje.v2n1p62

Bell, M. (2011). Define academic performance. Retrieved 8/2/2011 from http://www.ehow.com/about 4740750 define-academicperformance.htm/\#ixzz/TroG8w7A

Bolarinwa, D. A. (2014). The impact of administrative duties of the school heads on the implementation of Universal Basic Education in South-west, Nigeria. Unpublished Phd Thesis, Department of Educational Management, Faculty of Education, Ekiti State 
University, Ado-Ekiti, Nigeria.

Chen, Y., Cheng, J., \& Sato, M. (2016). Effect of school principals' leadership behaviours: A comparison between Taiwan and Japan. Educational Sciences: Theory and Practice, 17(1), 145-173.

Cypres, A., \& Breckner, J. (2013). Great leaders equal great schools: Alliances and discourse for educational reform. IAP.

Daramola, O. D. (2017). Effect of teachers' participation in staff development programmes and students' academic performance in secondary schools in Ekiti State, Nigeria. Unpublished M.Ed Thesis, Department of Educational Management, Faculty of Education, Ekiti State University, Ado-Ekiti, Nigeria.

Day, C., \& Sammons, P. (2016). Successful school leadership, Education Development Trust, University of Nottingham, Malasia.

Dojumo, T. M. (2019). Personnel management and academic performance of secondary school students in Ondo State, Nigeria. Unpublished M.Ed Thesis, Department of Educational Management, Faculty of Education, Ekiti State University, Ado-Ekiti, Nigeria.

Duze, C. O. (2012). The changing role of school leadership and teacher capacity building in teaching and learning. Journal of Emerging Trends in Educational Research and Policy Studies, 3(1), 111-117.

Federal Republic of Nigeria. (2014). National Policy on Education. National Educational Research and Development Council Press.

Gebreselassie, M. (2015). Principals' roles in fostering teachers' continuous professional development in government secondary schools of Addis Ababa. Unpublished $\mathrm{PhD}$ Thesis, Addis Ababa University, Ethiopia.

Glickman, C., A Gordon, S., \& Ross-Gordon, J. (2007). Supervision and instructional leadership: Developmental approach. Pearson Education Inc.

House, B. J. (1971). A path-goal theory of leadership effectiveness. Administrative Science Quarterly, 16(3), 321-338. https://doi.org/10.2307/2391905

Ilesanmi, F. T. (2017). Human resource management and students' academic performance in public secondary schools in Ekiti State, Nigeria Unpublished M.Ed Thesis, Department of Educational Management, Faculty of Education, Ekiti State University, Ado-Ekiti, Nigeria.

Kathryn, D. (2010). Academic performance achievement. Retrieved June 14, 2011 from http://www.nichgy.org.

Kayode, G.M., \& Ayodele, J. B. (2015). Impact of teachers' time management on secondary school students' academic performance in Ekiti State, Nigeria. International Journal of Secondary Education, 3(1), 1-7. https://doi.org/10.11648/j.ijsedu.20150301.11

Luthans, F. (2007). Organisational behaviours. McGraw Hill.

Maimela, M. M., \& Monyatsi, P. P. (2016). Strategies for omproving the academic performance of students in Botswana primary schools. World Journal of Education Research, 3(1), 157. https://doi.org/10.22158/wjer.v3n1p157

Maulana, A. A. (2012). Perception of school supervisor and teacher towards school supervisor role in improving high school education quality in Cirebon City. Unpublished 
Thesis, Faculty of Social and Political Sciences, Administrative Science Programme, University of Indonesia.

McGregor, D. (1960). Human side of enterprise. McGraw-Hill.

Nwesiga, A., \& Ogoti, E. (2018). Effectiveness of heads of schools in supervising teachers' teaching activities in secondary schools in Kagera Region, Tanzania. International Journal of Scientific Research and Management, 6(4), 91-117. https://doi.org/10.18535/ijsrm/v6i4.sh04

Ogunsola, A. T. (2018). Management of teaching personnel and students' academic performance in secondary schools in Ekiti State, Nigeria Unpublished M.Ed Thesis, Department of Educational Management, Faculty of Education, Ekiti State University, Ado-Ekiti, Nigeria.

Okendu, J. N. (2012). The influence of instructional process and supervision on academic performance of secondary school students of Rivers State, Nigeria. Research International Journal, 3(1), 147-151.

Okorie, A. N. (2014). Relationship among peer pressure, time management and academic performance of in-school adolescents in Umuahaia Education Zone, Abia State, Nigeria. Unpublished M.Ed Thesis, Department of Educational Foundations, Faculty of Education, University of Nigeria, Nsukka, Nigeria.

Owadie, I. (2011, August 31). West African Senior School Certificate Examination results. The Punch, p. 39.

Popoola, O. B. (2017). Students' personality, teacher leadership styles as correlates of academic performance in Yobe State secondary schools. Unpublished M.Ed Thesis, Department of Educational Management, Faculty of Education, Ekiti State University, Ado-Ekiti, Nigeria.

Sam, O. (2011, May 25). Mass failures worries stakeholders. The Sun, p. 24.

Stephen, S. (2014). The importance of education for sustainable development.

Uysal, S., Aydin, A., \& Sarier, Y. (2013). The effect of school principals' leadership styles on teachers' organizational commitment and job satisfaction. Educational Services: Theory and Practice, 13(2), 806-811.

Wolhuter, C., Walt, H., \& Steyn, H. (2016). A strategy to support educational leaders in developing countries to manage contextual challenges. South African Journal of Education

Zaka, P. (2013). A case study of blended teaching and learning in a New Zealand secondary school using an ecological framework. Journal of Open, Flexible, and Distance Learning, 1(1), 35-38.

\section{Copyright Disclaimer}

Copyright reserved by the authors.

This article is an open-access article distributed under the terms and conditions of the Creative Commons Attribution license (http://creativecommons.org/licenses/by/4.0/). 